\title{
Comments: "Evolution and projection of knee arthroplasty from 2003 to 2030 in the state of São Paulo"
}

1. Docente da Universidade Federal de São Paulo, departamento de Ortopedia e Traumatologia, programa de Pós-Graduação em Ciências da Saúde Aplicada ao Esporte e à AtividadeFísica Contact: leo_ramos@hotmail.com

The aging of the Brazilian population, as a result of increased life expectancy, contributes to the increase of the arthroplasties at a national level. ${ }^{1-3}$ Several studies have demonstrated that this increase reflects a worldwide trend. Other places, such as the United Kingdom and Australia, saw an increase in the number of arthroplasties during the same period, even though life expectancy there is greater than in Brasil. ${ }^{2-5}$ Over 76 years, from 1940 to 2016, the life expectancy of the Brazilians at birth increased in more than 30 years and today is 75.8 years, an increase of 3 months and 11 days compared to 2015, according to the Brazilian Institute of Geography and Statistics (IBGE). Data from the 2016 Mortality Table showed that, on average, women live longer than men. While the life expectancy of men, in 2016, was 72.9 years, women's reached 79.4 years. ${ }^{1}$ These potential patients need public policies for the prevention and treatment of osteoarthritis. The treatment of osteoarthritis is of fundamental importance to public health and surgery is only one many treatment possibilities; however, it is the most expensive and with the greatest rate of complications. The procedure complications are related to factors concerning the material and technique used. ${ }^{6}$ The knowledge on how arthroplasty surgeries behave in our midst provides important material for health policies and exposes the need for trained specialists and more tertiary health care centers, which could enable these individuals to resume their productive activities, an essential outcome to the national economic scenario and an important psychosocial factor. Therefore, the discussion on the necessity of a National Arthroplasty Record is of the utmost importance. In July 2015, in Brasilia, an inter-institutional working group on prostheses and special materials published its final report, in which they stress this need. The knowledge of how Brazilian surgeons treat their patients, the type of implant, brand, complications, and survival of these procedures provide basic information so that the most interested party in this whole process, the patient, can truly benefit from it,by being completely included in society, in full activity. ${ }^{7}$

\section{REFERENCES}

1. Instituto Brasileiro de Geografia e Estatística (IBGE). Tábua completa de mortalidade para o Brasil - 2017 Breve análise da evolução da mortalidade no Brasil. Brasília: Ministério do Planejamento, Desenvolvimento e Gestão; 2018. [cited 2018 Jun 23]. Available from: ftp://ftp.ibge.gov.br/Tabuas_Completas_de_MortalidadeTabuas_Completas_de_Mortalidade_2017/tabua_ de_mortalidade_2017_analise.pdf

2. Carvalho RT, Lopes TL, Lima JHS, Arrebola LS, Colombo ML, Takano MI. Evolution and projection of knee arthroplasty from 2003 to 2030 in the state of São Paulo. Rev Assoc Med Bras. 2019; 65(7) 1001-1006.

3. Carvalho RT, Canté JC, Lima JH, Tavares LA, Takano MI, Tavares FG. Prevalence of knee arthroplasty in the state of São Paulo between 2003 and 2010. Sao Paulo Med J. 2016;134(5):417-22.

4. March LM, Bagga H. Epidemiology of osteoarthritis in Australia. Med J Aust. 2004;180(5 Suppl):S6-10.

5. Ibrahim T, Bloch B, Esler CN, Abrams KR, Harper WM. Temporal trends in primary total hip and knee arthroplasty surgery: results from a UK regional register, 1991-2004. Ann R Coll Surg Engl. 2010;92(3):231-5.

6. Khan M, Osman K, Green G, Haddad FS. The epidemiology of failure in total knee arthroplasty: avoiding your next revision. Bone Joint J. 2016;98B(1 Suppl A):105-12.

7. Grupo de Trabalho Interinstitucional sobre órteses, próteses e materiais especiais (GTI-OPME). Relatório final. Brasília: Ministério da Saúde; 2015. [cited 2018 Jun 23]. Available from: http://portalarquivos.saude.gov.br/ images/pdf/2015/julho/07/Relatorio-Final-versao-final-6-7-2015.pdf 